\title{
Trophic ecology of the family Artedidraconidae (Pisces: Osteichthyes) and its impact on the eastern Weddell Sea benthic system
}

\author{
Ignacio Olaso ${ }^{1, *}$, Martin Rauschert $^{2}$, Claude De Broyer ${ }^{3}$ \\ ${ }^{1}$ Instituto Español de Oceanografía, Laboratorio Oceanográfico de Santander, Apartado 240, 39080 Santander, Spain \\ ${ }^{2}$ AWI Potsdam, Institut für spezielle Zoologie Berlin, Invalidenstr. 43, 10115 Berlin, Germany \\ ${ }^{3}$ Institut Royal des Sciences Naturelles de Belgique, Rue Vautier 29, 1000 Bruxelles, Belgium
}

\begin{abstract}
The family Artedidraconidae comprises small, endemic Antarctic fishes, known as plunderfish, mostly distributed in the High Antarctic region. To study the diet of these specialised benthic feeders, stomach contents of the 11 most abundant species in the eastern Weddell Sea were examined. Prey composition was identified to the lowest taxonomic level for peracarid crustaceans and polychaetes. Half of the food volume comprised 36 crustacean taxa ( 26 of which were amphipods). The other half was made up of 7 polychaete taxa and 8 other zoological groups. The diet of plunderfishes $<20 \mathrm{~cm}$ long was found to include about $70 \%$ peracarid crustaceans, $50 \%$ of which were amphipods, mainly gammarids; the rest of their diet was mostly sessile and motile polychaetes. Individuals larger than $15 \mathrm{~cm}$ began to prey on other fishes, although gammarids were still a part of their diet. The size of prey ranged from 5 to $32 \mathrm{~mm}$. The mean size of prey increased with predator size. Selective predation effects were observed: small prey (copepods, cumaceans, ostracods, the gammarid family Eusiridae s.l. and the polychaete family Phyllodocidae) were found more frequently in small predators, whereas large prey (Epimeriidae, Lysianassidae 5.I., Cirolanidae, Arcturidae, Crangonidae, Euphausiidae, Pycnogonida) appeared in the stomachs of predators larger than a certain size. Plunderfish prey are generally abundant in the area, but the high diversity of the diet found in the genus Artedidraco, compared with the genera Dolloidraco and Pogonophryne, was surprising. The present analysis is based on data concerning the distribution and abundance of predators, as well as biological knowledge regarding the most characteristic types of prey. The specialised diets of plunderfishes from different habitats and of different sizes are also compared, in order to more closely examine the feeding strategy of the family Artedidraconidae, and roughly quantify its impact on the benthic trophic web.
\end{abstract}

KEY WORDS: Benthic feeders - Artedidraconids - Trophic relationships - Amphipods - Polychaetes . Weddell Sea

\section{INTRODUCTION}

Benthic feeders are common among Antarctic coastal fish species, but, in the High Antarctic, the species feeding primarily on benthic organisms are particularly numerous (Kock 1992). In the eastern Weddell Sea, $95 \%$ of the bottom-dwelling fish belong to the perciform suborder Notothenioidei (Ekau 1990), which has adapted very well to High Antarctic conditions.

·E-mail: iolaso@st.ieo.es
Most of these species live at depths of $<1000 \mathrm{~m}$ (Eastman 1991). The notothenioid family Artedidraconidae is well represented in the High Antarctic, where 23 of the 24 known species of the family's 4 genera have been recorded (Kock 1992). These fishes are rather small, reaching rarely more than $34 \mathrm{~cm}$ long (Eakin 1990). They have been the subject of a number of taxonomic studies (Eakin 1977, 1981, 1987, Eakin \& Kock 1984, Balushkin 1988).

They are typical specialised benthic feeders and quite sedentary (Hubold 1991), usually remaining motionless on the substratum. These fish are commonly 
known as barbeled plunderfishes, because they have fleshy filaments, or barbels, hanging from their mouths. They typically use the sit-and-wait predation method, known as ambush feeding, catching only moving prey and ignoring those that are clearly visible but immobile (Daniels 1982, Hubold 1991). The barbel is used as a lure, and is also a tactile somatosensory organ (Janssen et al. 1993). Despite the interesting predatory methods of this endemic Antarctic family, few studies have been conducted on its feeding habits. Wyanski \& Targett (1981) analysed the contents of 179 stomachs from 8 species of artedidraconids in different Antarctic areas, and found that they feed on select species, in particular on infaunal and epifaunal polychaetes, molluscs and amphipods. These authors were the first to investigate this family's feeding biology; later, Schwarzbach (1988) studied the diet of 6 species in the eastern and southern Weddell Sea, and published data on their prey spectra. Both articles showed that Artetidraconidae prey upon a wide range of zoological groups.

In the present paper, we examine the feeding biology of these benthic-feeding fish from the Weddell Sea, focusing on the importance of peracarid crustaceans and polychaetes in their diet. A detailed taxonomic study of the most characteristic prey groups has been conducted in order to determine the impact of benthos-plunderfish interactions on the ecosystem, and to estimate the degree of predation sustained by certain benthic groups.

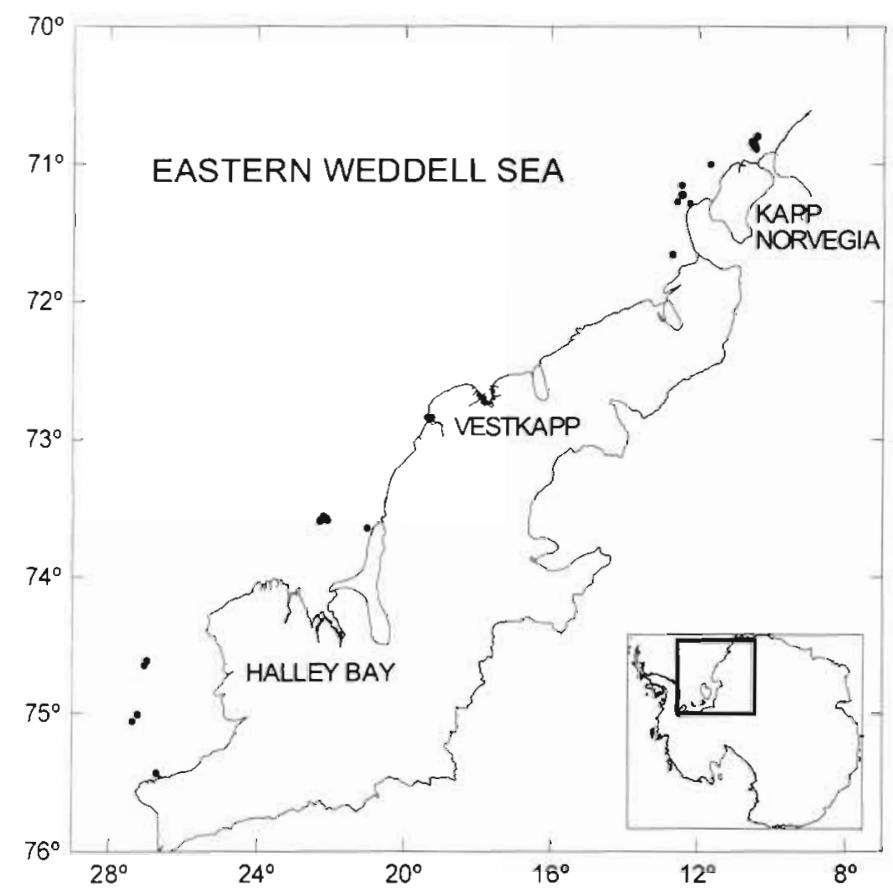

Fig. 1 Location of hauls $(\bullet)$ in the Weddell Sea during the ANT XV/III cruise, summer 1998

\section{MATERIALS AND METHODS}

The ANT XV/III cruise, aboard the RV 'Polarstern', was conducted in the eastern Weddell Sea (Fig. 1), from 13 January to 26 March 1998 (Arntz \& Gutt 1999). Sampling was carried out using different bottomtrawling equipment (Table 1). At each station, weight, total length (rounded down to the nearest centimetre), and sex were recorded for each plunderfish caught, and the maturity stage was determined according to a 5 -stage scale (Kock \& Kellermann 1991).

The stomach contents of plunderfishes were analysed on board ship. The volume of total prey groups (ml) in the stomach was measured using a trophometer, a calibrated instrument consisting of several different-sized half-cylinders built into a tray (Olaso \& Rodriguez-Marín 1995). The relationship between estimated volume and actual weight of the stomach contents was derived from a logarithmic model $(a=$ $0.932735, b=0.99324, r^{2}=0.995 ; p<0.01$ ). In species sensitive to pressure changes, stomach contents had been altered by regurgitation; therefore, the state of the gall bladder was examined (Robb 1992) in order to separate the empty stomachs of specimens that had regurgitated food shortly before being caught from the stomachs that were truly empty. Stomachs containing food that had been ingested during the haul itself (i.e. the gall bladder had not been exercised) were considered empty.

Fish, crustaceans and molluscs were identified by species, but other groups were combined into higher taxa. For determining prey taxa, we referred to Gon \& Heemstra (1990) for fish, Barnard \& Karaman (1991) and Brandt (1991) for peracarid crustaceans, Hain (1990) for molluscs, Hartmann-Schröder (1986) and Hartmann-Schröder \& Rosenfeldt (1992) for polychaetes, and Sieg \& Wägele (1990) for other groups. For each prey species, the following information was collected: percentage contribution to the volume of stomach contents, number of items per stomach, and state of digestion (Olaso 1990). To examine the relationship between prey size and predator size, the volume and weight of each prey were determined, and measurements of prey were taken in $\mathrm{mm}$ : in fish, total length, in crustaceans, total length from the apex of the head to the end margin of the telson; in the remaining prey, except for polychaetes, we measured them at their longest point. In the case of polychaetes, most of which are long and thin, we manipulated the specimens to a thickness of $10 \mathrm{~mm}$, and then measured their length.

Methods used to assess the relative importance of individual prey taxa were frequency of occurrence, $F_{i}$ numerical percentage, $N_{i}$ volume percentage, $V_{i}$ and weight percentage, $W$ (Hyslop 1980). To determine the 
Table 1. Situation and number of hauls by bottom trawl (GSN), Agassiz trawl (AGT), epibenthic sledge (EBS), and dredge (D), during ANT XV/III in February 1998

\begin{tabular}{|c|c|c|c|c|c|}
\hline Station & Gear & \multicolumn{2}{|c|}{ Coordinates } & $\begin{array}{l}\text { Depth } \\
\text { (m) }\end{array}$ & $\begin{array}{l}\text { Time } \\
\text { (min) }\end{array}$ \\
\hline 71 & GSN & 70.4830 & 10.2600 & 291 & 21 \\
\hline 78 & GSN & 72.5090 & 19.1870 & 390 & 17 \\
\hline 220 & GSN & 70.5090 & 10.3550 & 254 & 9 \\
\hline 222 & GSN & 70.5100 & 10.3560 & 250 & 10 \\
\hline 82 & GSN & 72.5080 & 19.2190 & 406 & 15 \\
\hline 84 & GSN & 72.5080 & 19.1910 & 393 & 14 \\
\hline 263 & GSN & 72.5100 & 19.1520 & 386 & 10 \\
\hline 95 & GSN & 73.3400 & 22.1230 & 893 & 15 \\
\hline 120 & GSN & 73.3400 & 22.1220 & 877 & 15 \\
\hline 100 & GSN & 73.3570 & 22.0440 & 442 & 16 \\
\hline 97 & GSN & 73.3590 & 22.1600 & 644 & 14 \\
\hline 123 & GSN & 73.3610 & 22.1720 & 654 & 15 \\
\hline 150 & GSN & 74.3720 & 26.5860 & 734 & 15 \\
\hline 154 & GSN & 74.3920 & 27.0120 & 576 & 10 \\
\hline 167 & GSN & 75.0390 & 27.2130 & 406 & 5 \\
\hline 168 & GSN & 75.2640 & 26.4290 & 230 & 4 \\
\hline 165 & EBS & 75.0080 & 27.1350 & 398 & 10 \\
\hline 128 & $\mathrm{D}$ & 73.3910 & 20.5960 & 213 & 37 \\
\hline 103 & AGT & 73.3500 & 22.0700 & 614 & 9 \\
\hline 277 & AGI & 71.1800 & 12.1500 & 184 & 10 \\
\hline 44 & AGT & 70.5190 & 10.3380 & 228 & 3 \\
\hline 58 & $A G T$ & 70.5220 & 10.2900 & 245 & 10 \\
\hline 39 & $\mathrm{AGT}$ & 70.5260 & 10.3190 & 240 & 10 \\
\hline 77 & $\mathrm{AGT}$ & 71.0990 & 12.2920 & 341 & 10 \\
\hline 206 & $A G T$ & 71.0070 & 11.4250 & 598 & 15 \\
\hline 194 & AGT & 71.1400 & 12.2760 & 245 & 10 \\
\hline 197 & AGT & 71.1710 & 12.3600 & 416 & 5 \\
\hline 189 & AGT & 71.4010 & 12.4320 & 246 & 8 \\
\hline 62 & AGT & 70.5370 & 10.2820 & 238 & 8 \\
\hline
\end{tabular}

degree of feeding specialisation of each predator group we used the Shannon-Wiener diversity index, $H$ (Sannon \& Weaver 1949):

$$
H=-\sum_{i=1}^{S} P_{i} \ln p_{i}
$$

where $p_{i}$ is the proportion of prey taxa $i$ in the diet, with $S$ the total number of different prey categories consumed by the predator. We also considered evenness: $J=H / \ln S$ (Pielou 1966). This index is a measurement of the degree of uncertainty (Krebs 1972), so that the higher the diversity value, the higher the uncertainty. We were interested in comparing the feeding habits of fishes with the availability of potential food resources in their natural habitats. To do so, we used Ivlev's electivity index (Ivlev 1961), which characterises the degree of selection of a particular prey species by the predator being studied. The relationship is defined as:

$$
E=\left(r_{1}-p_{1}\right) /\left(r_{i}+p_{i}\right)
$$

where $E$ is the measure of selectivity, $r_{1}$ the relative abundance of prey item $i$ in the gut (as a weight per- centage of the total gut contents), and $p_{1}$ is the relative abundance of same prey item in the environment (defined as a biomass percentage of total benthos in the study area; these data were taken from Brey \& Gerdes 1998, Gerdes unpubl. data). We chose this index because it is generally considered to be unbiased, and relatively independent of sample size.

To compare our values of biomass and consumption with those of other authors, we carried out conversions using wet weight to dry weight and dry weight to carbon, following Jorgensen et al. (1991). In fish we assume a wet weight to carbon ratio of 10 according to Jarre-Teichmann et al. (1997).

\section{RESULTS}

We analysed the contents of 219 stomachs from 11 species of plunderfishes belonging to the genera Artedidraco, Dolloidraco and Pogonophryne (Table 2). These constitute nearly all of the artedidraconids collected, the most abundant species being $D$. Iongedorsalis, A. orianae, A. skottsbergi, $P$. marmorata and $A$. 
Table 2. Artedidraconidae. Number of individuals caught and number of stomachs sampled by species

\begin{tabular}{|c|c|c|c|c|c|}
\hline Species & $\begin{array}{l}\text { Length } \\
\text { (cm) }\end{array}$ & $\begin{array}{l}\text { No. of fish } \\
\text { caught }\end{array}$ & $\begin{array}{l}\text { Total no. } \\
\text { of stomachs }\end{array}$ & Regurgitated & $\begin{array}{c}\% \\
\text { empty }\end{array}$ \\
\hline Artedidraco loennbergi & $7-11$ & 20 & 20 & 1 & 20 \\
\hline Artedidraco skottsbergi & $3-12$ & 52 & 42 & & 19 \\
\hline Artedidraco orianae & $5-16$ & 58 & 58 & & 7 \\
\hline Artedidraco shackeltoni & $5-10$ & 11 & 4 & & 50 \\
\hline Dolloidraco longedorsalis & $9-13$ & 215 & 43 & & 19 \\
\hline Pogonophryne lanceobarbata & $6-10$ & 6 & 6 & & 0 \\
\hline Pogonophryne marmorata & $6-21$ & 26 & 22 & & 32 \\
\hline Pogonophryne phyllopogon & $8-22$ & 8 & 8 & & 25 \\
\hline Pogonophryne barsukovi & $11-21$ & 12 & 12 & 1 & 42 \\
\hline Pogonophryne macropogon & $37-37$ & 1 & 1 & & 0 \\
\hline Pogonophryne scotti & $19-29$ & 5 & 3 & & 67 \\
\hline Total & & 414 & 0 & 2 & 19 \\
\hline
\end{tabular}

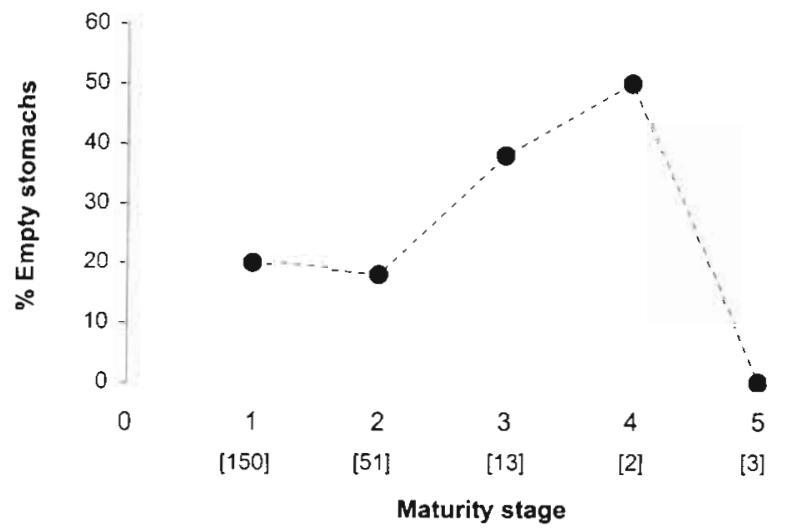

Fig. 2. Percentage of empty stomachs of the 11 artedidraconid species sampled, with regard to their maturity stage; in brackets: total no. of stomachs at each maturity stage

loennbergi. Few cases of regurgitation were observed. A total of $19 \%$ of the stomachs were empty, and only 2 of them had been regurgitated. This percentage of empty stomachs seems a little high, since other authors have reported a percentage of empty stomachs of $<10 \%$ for this family (Targett 1981). However, in the present study the adults of some species (P. marmorata, Artedidraco spp.) showed very mature gonads, meaning that they were close to spawning, as can be seen in Fig. 2. It should be remembered that the state of maturity can cause an overestimation of the number of empty stomachs, since the gonad mass can occupy more than $25 \%$ of the body's total volume, and under these conditions feeding intensity usually drops. In the spawning and pre-spawning periods of other Antarctic fish species, an increase in the proportion of empty stomachs has been also observed (e.g. Duhamel \& Hureau 1985, Gorelova \& Shandikov 1988).

\section{Interspecific variation in the diets of artedidraconids}

Table 3 shows the diet, expressed in percentages of volume, of the 5 most abundant species of artedidraconids. Artedidraco orianae preyed on errant polychaetes, phyllodocids and polynoids, and on the majority of the crustacean groups, above all amphipods. It showed the highest taxonomic diversity, 4.12, and consumed different families of gammarideans, with especially noteworthy consumption of Epimeriidae. A. skottsbergi consumed the same percentage of amphipods as $A$. orianae, but that of polychaetes (polynoids and aphroditiids) was lower; however, its diet included other zoological groups, and also presented high taxonomic diversity. Its habits seem more benthic than those of $A$. orianae. For its part, $A$. loennbergi exhibited fewer benthic feeding habits than the 2 former species, since its prey were mostly found above the seafloor, e.g. mysids, with only $17 \%$ polychaetes; the rest of its diet comprised gammarideans. In all, its prey taxa diversity was much lower.

Dolloidraco longedorsalis were captured in a limited length range. This species consumed a high percentage of polychaetes, nearly $50 \%$, among which we found the wide-ranging aphroditiids and the sedentary terebellids, maldanids and spionids. The species also fed on gammarids ( $35 \%$ ), and even krill, cumaceans, isopods and other invertebrates. The taxonomic diversity was high. Pogonophryne marmorata's diet was nearly $60 \%$ crustaceans, above all, large cirolanids and gammarideans and mysids. Its consumption of polychaetes was not significant. Its taxonomic diversity, 2.72, was the lowest of the family. The other species of artedidraconids caught lacked the minimum stomach contents to analyse their diets; still, we can say that while all of the prey of Artedidraco shackeltoni were polychaetes, these organisms were not found 
Table 3. Diet of the 5 most abundant artedidraconid species (with length range). Data expressed in percentage by volume + : value $<1 \%$

\begin{tabular}{|c|c|c|c|c|c|}
\hline \multirow[t]{2}{*}{ Prey taxon } & \multicolumn{5}{|c|}{ Predator species } \\
\hline & $\begin{array}{c}\text { Artedidraco } \\
\text { onanae } \\
(5-16 \mathrm{~cm})\end{array}$ & $\begin{array}{c}\text { Artedidraco } \\
\text { skottsbergi } \\
(3-12 \mathrm{~cm})\end{array}$ & $\begin{array}{c}\text { Artedidraco } \\
\text { loennbergi } \\
(7-11 \mathrm{~cm})\end{array}$ & $\begin{array}{c}\text { Dolloidraco } \\
\text { longedorsalis } \\
(9-13 \mathrm{~cm})\end{array}$ & $\begin{array}{c}\text { Pogonophryne } \\
\text { marmorata } \\
(5-21 \mathrm{~cm})\end{array}$ \\
\hline Crustacea & 58 & 59 & 77 & 46 & 97 \\
\hline Amphipoda & 40 & 41 & 62 & 36 & 59 \\
\hline Phtisicidae & 7 & & & & 4 \\
\hline Gammaridae & 32 & 39 & 62 & 36 & 55 \\
\hline Ampeliscidae & & 12 & & & \\
\hline Eusiridae & 4 & 5 & & 7 & 8 \\
\hline Epimeriidae & 16 & 6 & & & 30 \\
\hline Gammaridae undetermined & 2 & 8 & 25 & 8 & 7 \\
\hline $\begin{array}{l}\text { Iphimediidae } \\
\text { Ischyroceridae }\end{array}$ & 2 & & & & \\
\hline Leucothoidae & 1 & & & & \\
\hline Liljeborgidae & 1 & & & & 7 \\
\hline Lyssianassidae & & & 37 & 16 & 3 \\
\hline Oedicerotidae & & 3 & & & \\
\hline Phoxocephalidae & 1 & 2 & & 6 & \\
\hline Podoceridae & 1 & & & & \\
\hline Stenothoidae & 4 & 1 & & & \\
\hline Synopiidae & & 2 & & & \\
\hline Hyperiidae & 2 & 2 & & & \\
\hline Copepoda & 1 & & & & \\
\hline Cumacea & & 15 & & 6 & \\
\hline $\begin{array}{l}\text { Isopoda } \\
\quad \text { Cirolanidae }\end{array}$ & 10 & 1 & 6 & 1 & $\begin{array}{l}21 \\
18\end{array}$ \\
\hline Gnathiidae & + & & & & \\
\hline Isopoda undetermined & 1 & 1 & 6 & 1 & 3 \\
\hline Munnidae & 1 & & & & \\
\hline Valvifera & 7 & & & & \\
\hline Euphausiacea & 5 & & & 3 & \\
\hline Mysidacea & & & 9 & & 17 \\
\hline Ostracoda & 2 & 2 & & & \\
\hline Pycrogonida & 5 & & & & \\
\hline Holothuroidea & & 1 & & & \\
\hline Mollusca & & 5 & & & \\
\hline Bivalvia & & 3 & & & \\
\hline Gastropoda & & 2 & & & \\
\hline Hirudinea & 1 & & & & \\
\hline Bryozoa & & 4 & & & \\
\hline Cnidaria & & 1 & & 6 & \\
\hline Anthozoa & & & & 4 & \\
\hline Hydrozoa & & 1 & & 2 & \\
\hline Polychaeta & 36 & 30 & 23 & 48 & 3 \\
\hline Aphroditiidae & & & & 13 & \\
\hline Nephthyidae & & 7 & & & \\
\hline Maldanidae & & & & 21 & \\
\hline Phyllodocidae & 3 & & & & \\
\hline Polychaeta undetermined & & & 23 & & 3 \\
\hline Polynoidae & 28 & 14 & & & \\
\hline Spionidae & & & & 4 & \\
\hline Terebellidae & 6 & 10 & & 10 & \\
\hline Stomachs with food & 54 & 34 & 15 & 35 & 15 \\
\hline Mean replication & 0.7 & 0.4 & 0.3 & 0.4 & 0.7 \\
\hline Mean length & 11.4 & 8.4 & 9.1 & 10.3 & 11.6 \\
\hline No. of phyla & 4 & 6 & 2 & 3 & 2 \\
\hline No of taxa & 28 & 19 & 4 & 14 & 10 \\
\hline Taxa diversity & 4.12 & 3.72 & 1.53 & 3.50 & 2.72 \\
\hline Evenness & 0.86 & 0.88 & 0.77 & 0.92 & 0.82 \\
\hline
\end{tabular}




$\begin{array}{lll}\text { - Oth. Polychaeta } & \text { OPolynoidae } & \triangle \text { Amphipoda } \\ \text { 口Cumacea } & \text { Isopoda } & \diamond \text { Ostracoda } \\ \text { +Suprabenthic crust. XOth. Invertebrata } & \end{array}$

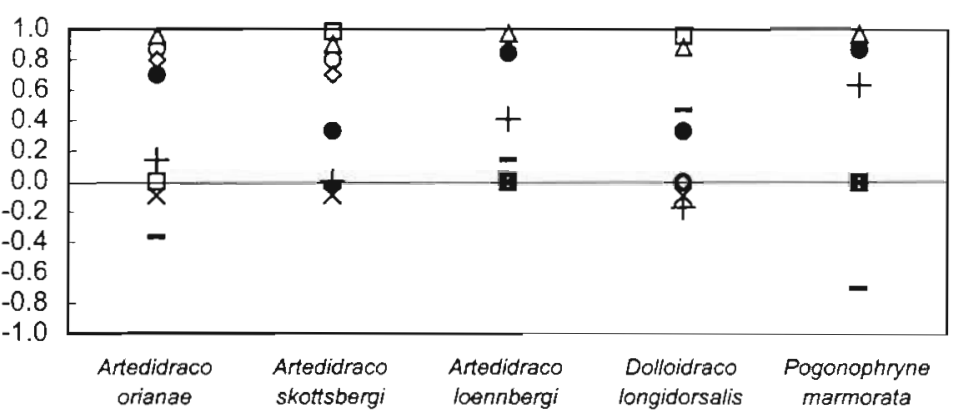

Fig. 3. Ivlev's electivity index, calculated for each prey group in the diets of the study area's 5 most abundant artedidraconid species among its prey. The most important of thiese were gammaridean amphipods ( $42 \%$ by number and $27.8 \%$ by volume), and motile and sessile polychaetes. Characteristic gammarid prey were species from the families Epimeriidae (e.g. Epimeria georgiana), Eusiridae s.l. (e.g. Prostebinggia gracilis, Rhachotropis sp.), Lysianassidae s.l. (Tryphosella murrayi) and Phoxocephalidae (Table 4). In addition to amphipods, 7 other groups of crustaceans were represented in the diet, with isopods and cumaceans being found in $7 \%$ of the stomachs. More than $25 \%$ of plunderfish prey (in terms of frequency and number) were polychaetes, mostly epibenthic species, such as the epibenthic polynoids and aphroditiids, although they also consumed infaunal prey (phyllodocids and terebellids, e.g. Begstroemia sonitki and Axionice spinifera).

Fig. 4 shows that plunderfishes preferentially selected amphipods, cumaceans, isopods, ostracods and polynoids, although their mean biomass was small. In contrast, the remaining polychaetes, which were abundant, were not actively selected. Suprabenthic crustaceans (euphausiids, mysids and decapods) and other invertebrates (e.g. cnidarians, bryozoans, pantopods and molluscs) were preyed upon in proportion to their abundance.

\section{Change of prey with predator size}

In order to examine the relative impact of benthic prey in the different size-categories of plunderfishes, we determined their volume (expressed as a percentage) in the diet, by size-range (Fig. 5). In artedidraconid specimens measuring up to $20 \mathrm{~cm}$, crustaceans represented about $2 / 3$ of the food consumed, with gammarids accounting for $40 \%$ of volume, except for the 15 to $19 \mathrm{~cm}$ size-range. Species of Eusiridae s.l. were the most common prey of smaller plunderfishes, but their importance disappeared at $12 \mathrm{~cm}$, while individuals from Lysianassidae s.l. and Epimeriidae appear in the diet of fish longer than $7 \mathrm{~cm}$ (Fig. 6). The genus Epimeria, from the latter family, became increasingly important as predator size rose. Isopods were preyed upon by all size categories of artedidraconids, their importance growing progressively with predator size. Some preys - e.g. copepods, cumaceans and the hyperiid Themisto gaudichaudiiappeared only in very small fish, and others appeared from a certain size on, such as euphausiids and pycnogonids. Polychaetes represented $1 / 4$ of the diet from $4 \mathrm{~cm}$, with their percentage increasing gradually until it reached $39 \%$ at $12-14 \mathrm{~cm}$ (Fig. 5). At small sizes, there were phyllodocids, and later aphroditiids, maldanids and terebellids, with polynoids being most noteworthy. Fish 
Table 4. Percentage by frequency of occurrence $(F)$, number $(N)$, and volume $(V)$ of major food items in 219 stomachs of the 11 species of artedidraconid fish sampled

\begin{tabular}{|c|c|c|c|c|}
\hline Prey taxon & $\% F$ & $\% N$ & $\% V$ & No. of taxa \\
\hline Crustacea & 63.7 & 65.0 & 45.7 & 36 \\
\hline Amphipoda & 49.6 & 50.6 & 31.3 & 26 \\
\hline Aeginoides gaussi & 4.6 & 4.7 & 2.6 & \\
\hline Ampelisca richardsoni & 3.0 & 3.1 & 1.4 & \\
\hline Ampeliscidae undetermined & 1.5 & 1.5 & 0.8 & \\
\hline Atyloella magellanica & 0.7 & 0.8 & 0.5 & \\
\hline Atylopsis sp. & 0.7 & 0.8 & 0.5 & \\
\hline Corophiidae undetermined & 0.7 & 0.8 & 0.2 & \\
\hline Epimeria georgiana & 6.0 & 6.1 & 4.4 & \\
\hline Epimeria grandirostris & 0.7 & 0.8 & 0.4 & \\
\hline Epimeria macrodonta & 0.7 & 0.8 & 0.6 & \\
\hline Epimeria sp. & 3.0 & 3.1 & 7.7 & \\
\hline Epimeriidae undetermined & 0.7 & 0.8 & 0.7 & \\
\hline Eusiridae undetermined & 1.5 & 1.5 & 0.3 & \\
\hline Gammaridae undetermined & 2.2 & 2.3 & 1.5 & \\
\hline Iphimediidae undetermined & 0.7 & 0.8 & 0.5 & \\
\hline Leucothoe spinicarpa & 0.7 & 0.8 & 0.2 & \\
\hline Liljeborgiidae undetermined & 1.5 & 1.5 & 0.4 & \\
\hline Lysianassidae undetermined & 1.5 & 1.5 & 0.5 & \\
\hline Oedicerotidae undetermined & 0.7 & 0.8 & 0.4 & \\
\hline Paramoera sp. & 0.7 & 0.8 & 0.2 & \\
\hline Phoxocephalidae undetermined & 2.2 & 2.3 & 1.0 & \\
\hline Podoceridae undetermined & 0.7 & 0.8 & 0.2 & \\
\hline Prostebbingia gracilis & 1.5 & 1.5 & 0.5 & \\
\hline Pseudericthonius sp. & 0.7 & 0.8 & 0.2 & \\
\hline Rhachotropis sp. & 1.5 & 1.5 & 1.3 & \\
\hline Stenothoidae undetermined & 0.7 & 0.8 & 0.6 & \\
\hline Synopiidae undetermined & 0.7 & 0.8 & 0.1 & \\
\hline Torometopa sp. & 0.7 & 0.8 & 0.2 & \\
\hline Tryphosella murrayi & 0.7 & 0.8 & 0.1 & \\
\hline Tryphosella sp. & 3.0 & 3.1 & 2.1 & \\
\hline Unstes gigas & 0.7 & 0.8 & 0.4 & \\
\hline Waldeckia obesa & 0.7 & 0.8 & 0.2 & \\
\hline Themisto gaudichaudii & 3.4 & 3.5 & 0.9 & \\
\hline Copepoda & 1.2 & 1.2 & 0.2 & 1 \\
\hline Cumacea & 6.7 & 6.9 & 3.0 & 1 \\
\hline Cumacea undetermined & 4.3 & 4.4 & 2.0 & \\
\hline Cyclaspis gigas & 2.4 & 2.5 & 1.0 & \\
\hline Decapoda & 0.6 & 0.6 & 0.6 & 1 \\
\hline Notocrangon antarcticus & 0.6 & 0.6 & 0.6 & \\
\hline Euphausiacea & 1.8 & 1.9 & 2.5 & 1 \\
\hline Euphausia superba & 1.8 & 1.9 & 2.5 & \\
\hline Isopoda & 8.0 & 8.1 & 5.6 & 1 \\
\hline Natatolana meridionalis & 1.8 & 2.1 & 2.8 & \\
\hline Gnathia sp. & 1.8 & 2.0 & 0.2 & \\
\hline Munna sp. & 1.8 & 1.0 & 0.1 & \\
\hline Litarcturus bobinus & 2.6 & 3.0 & 2.4 & \\
\hline Mysidacea & 2.4 & 2.5 & 1.8 & 1 \\
\hline Antarctomysis maxima & 1.8 & 1.9 & 1.4 & \\
\hline Mysidacea undetermined & 0.6 & 0.6 & 0.3 & \\
\hline Ostracoda & 1.8 & 1.9 & 0.7 & 1 \\
\hline Pycnogonida & 1.5 & 1.5 & 1.2 & 1 \\
\hline Echinodermata & 0.5 & 0.5 & 0.1 & 1 \\
\hline Holothuroidea & 0.5 & 0.5 & 0.1 & 1 \\
\hline Mollusca & 2.0 & 2.1 & 1.1 & 2 \\
\hline Bivalvia & 0.7 & 0.7 & 0.7 & 1 \\
\hline Gastropoda & 1.4 & 1.4 & 0.4 & 1 \\
\hline
\end{tabular}


Table 4 (continued)

\begin{tabular}{|c|c|c|c|c|}
\hline Prey taxon & $\% F$ & $\% N$ & $\% V$ & No. of taxa \\
\hline Bryozoa & 1.0 & 1.0 & 0.4 & 1 \\
\hline Cnidaria & 2.0 & 2.1 & 0.6 & 2 \\
\hline Anthozoa & 1.0 & 1.0 & 0.3 & 1 \\
\hline Hydrozoa & 1.0 & 1.0 & 0.3 & 1 \\
\hline Hirudinea & 0.5 & 0.5 & 0.1 & 1 \\
\hline Polychaeta & 27.3 & 27.9 & 18.8 & 7 \\
\hline Aphroditiidae undetermined & 2.1 & 2.1 & 0.7 & 1 \\
\hline Maldanidae undetermined & 2.1 & 2.1 & 1.1 & 1 \\
\hline Aglaophamus sp. & 1.0 & 1.1 & 0.6 & 1 \\
\hline Bergstroemia sotniki & 3.1 & 3.2 & 1.0 & 1 \\
\hline Polynoidae & 13.6 & 13.9 & 11.9 & 1 \\
\hline Spionidae & 1.0 & 1.1 & 0.1 & 1 \\
\hline Axionice spinifera & 1.0 & 1.1 & 1.5 & 1 \\
\hline Terebel.lidae undetermined & 3.1 & 3.2 & 1.9 & \\
\hline Pisces & 1.0 & 0.7 & 31.9 & 1 \\
\hline Notothenioidei undetermined & 1.0 & 0.7 & 31.9 & \\
\hline
\end{tabular}

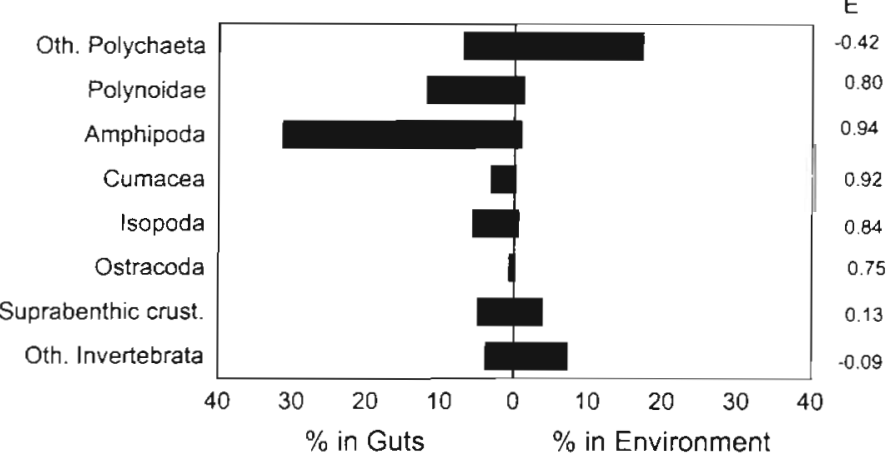

Fig. 4. Selectivity of prey groups in the family Artedidraconidae, representing the proportion of prey groups found in the gut and in the study area ( $E_{1}$ electivity index)

prey began to appear from $15 \mathrm{~cm}$, and from $20 \mathrm{~cm}$, smaller notothenioids and large epimeriid amphipods constituted the largest portion of the plunderfish diet.

\section{Prey size selection by artedidraconids}

All species of the family Artedidraconidae feed on small prey found at the bottom or above it, i.e. they are benthic and suprabenthic feeders. The range of prey species between 8 and $18 \mathrm{~cm}$ is practically the same, although the shapes and forms of benthic organisms vary greatly, and we do not know exactly the margin of error caused by comparing measurements taken from such different zoological groups. However, we believe that since the majority of prey were crustaceans, this information should be included. From $18 \mathrm{~cm}$, we found a slight trend for prey size to increase with predator size, which is when the artedidraconids began to con- sume fish, from 18 to $20 \mathrm{~cm}$ on. The crustacean prey found ranged from 4 to $33 \mathrm{~mm}$ (Table 4 ). The smallest prey were the copepods $(4 \mathrm{~mm})$, ostracods $(8 \mathrm{~mm})$ and cumaceans (up to $14 \mathrm{~mm}$ ), found in the stomach contents of the smallest plunderfishes. The amphipods showed a length ranging from 4 to $22 \mathrm{~mm}$, but most gammarids were small, 10 to $12 \mathrm{~mm}$; they consequently seem to form the basis of the artedidraconid diet. Medium-sized prey were isopods, sea spiders, euphausiaceans, decapods and mysidaceans, the latter reaching sizes of $30 \mathrm{~mm}$. Polychaetes, although they can become quite large, tended to be preyed upon only to a size of $20 \mathrm{~mm}$ due to their fragility and small energy value, but, since there is wide variability in the diameters of their bodies, these measurements cannot be compared with those of crustaceans. The only prey taxa larger than $30 \mathrm{~mm}$ were fish; a clear example of this was the case of prey in Pogonophryne. For crustacean prey and fish prey, the linear regression between predator length and prey length was statistically significant $\left(\mathrm{r}^{2}=0.341 ; a=-24.076 ; b=0.330 ; \mathrm{n}=121\right.$; $\mathrm{p}<0.001$ ), and although the fit was not very strong, there is a gradual increase in the prey-length groups according to the predator-length.

To avoid the variation produced between the forms and measurements of the different prey groups in the benthos, we compared predator size with the individual weights of prey (Fig. 7), and found a better relationship than with the size of the prey by means of a polynomial goodness-of-fit estimate $\left(\mathrm{r}^{2}=0.98 ; \mathrm{n}=191\right.$; $\mathrm{p}>0.001$ ). The weight range of the crustaceans varied between 0.04 and $2.41 \mathrm{~g}$; that of the copepods, cumaceans and ostracods was narrower $(0.1$ to $0.3 \mathrm{~g})$; the weight range of the polychaetes oscillated between 0.1 and $2.36 \mathrm{~g}$ (Table 5). 
a

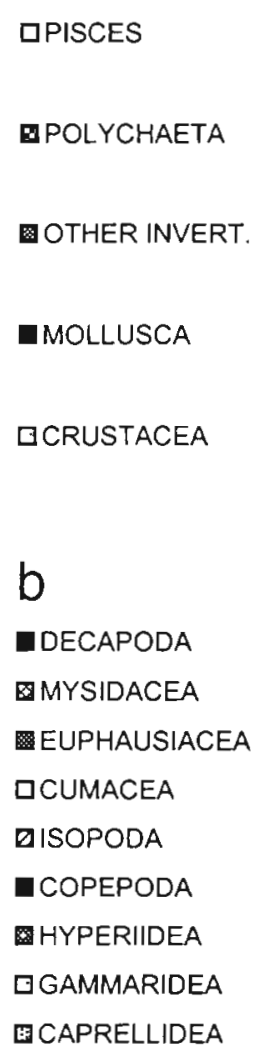

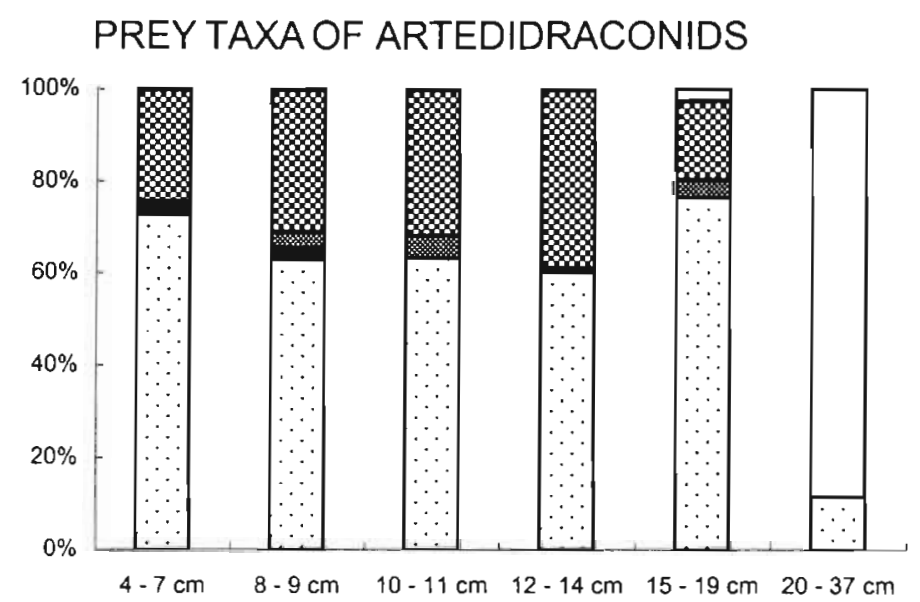

\section{Crustacean prey}
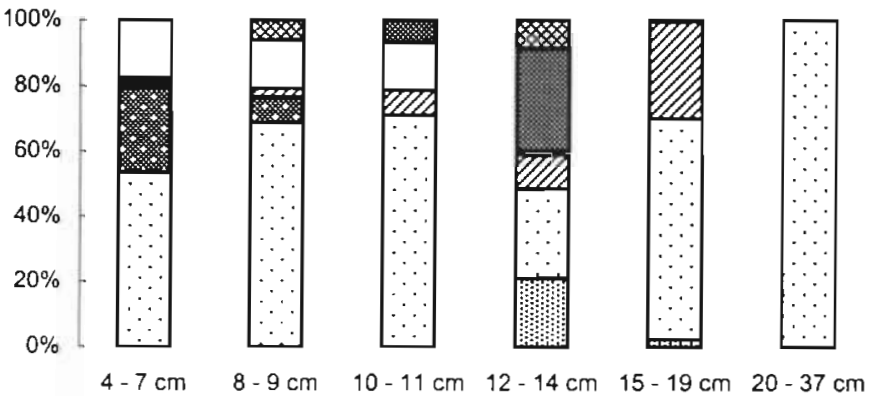

C

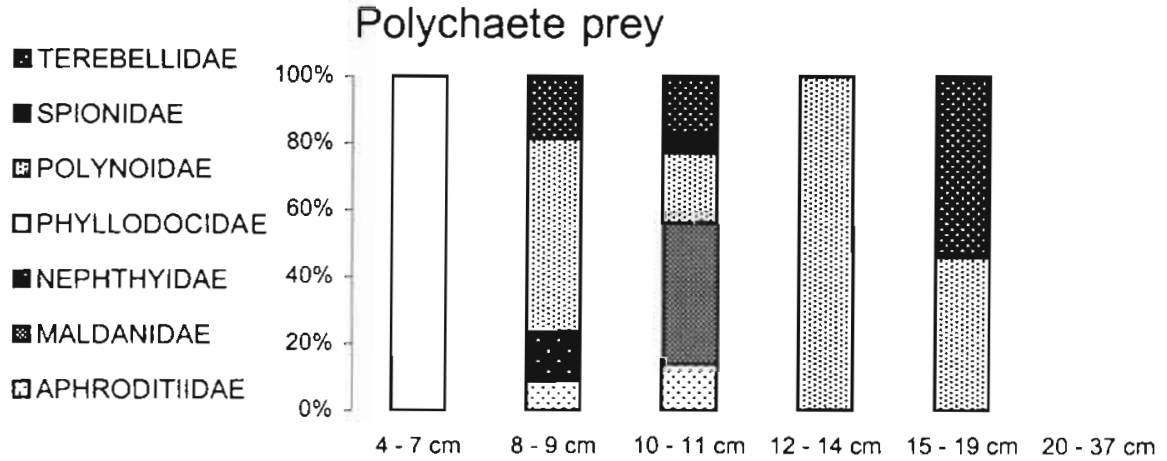

Fig. 5. Distribution of prey groups in the overall fish diet; data expressed in percentages of volume

\section{Distribution and abundance of the eastern Weddell Sea artedidraconid fishes, and change in prey composition with depth}

In our sample of plunderfishes we found that the number of artedidraconid species is greater in Kapp Norvegia and Vestkapp than in Halley Bay (Table 6). In the $200 \mathrm{~m}$ depth-range, a higher number of plunderfishes appeared in the Kapp Norvegia area than in
Halley Bay, although in terms of weight they were more similar; the most abundant species were of the genus Artedidraco. In the $400 \mathrm{~m}$ range, the highest abundance in terms of number was found at Kapp Norvegia, whereas in weight it was lower than in the other 2 areas, the genus Dolloidraco being the most abundant. In the $600 \mathrm{~m}$ stratum, we found the highest number in Halley Bay, and once again nearly all of the catch belonged to the genus Dolloidraco. In Vestkapp, 
nearly all of the plunderfish catch also belonged to this genus. In the $800 \mathrm{~m}$ stratum, few plunderfish appeared, all belonging to the genus Pogonophryne. We were unable to sample at all depths in the 3 different study areas, but our results coincide with previous studies on the distribution of the family Artedidraconidae in the eastern Weddell Sea, in which $D$. longedorsalis was the most abundant species (Schwarzbach 1986, Hubold 1991), presenting maximum abundances at depths of 400 to $500 \mathrm{~m}$, whereas the genus Artedidraco dominated in shallower waters (Ekau 1990).

In order to observe differences in artedidraconid feeding with depth, we examined their diets in different depth ranges. The stomachs of individuals caught at $>600 \mathrm{~m}$ were not considered, given their scarcity. Fig. 8 shows that in the $200 \mathrm{~m}$ range most of the prey taxa, 42 , were found $_{i}$ almost all of the groups of crustaceans and 8 different phyla were represented. From $400 \mathrm{~m}$, crustaceans were more abundant in the artedidraconid diet, but the number of total prey taxa dropped to 25 at $400 \mathrm{~m}$ and to only 10 at $600 \mathrm{~m}$. Nevertheless, it must be taken into account that in this last range the number of predators examined was lower. Polychaetes represented $22 \%$ of the number of prey on bottoms at $200 \mathrm{~m}$, polynoids and the phyllodocid Bergstroemia sotniki being the most characteristic groups, although aphroditiids and nephthyids were also found. At $400 \mathrm{~m}$, we found that sedentary terebellids and spionids accounted for $18 \%$, falling to $14 \%$ on bottoms at $600 \mathrm{~m}$. Regarding gammarids, we found that they were important in the diet at a depth of $400 \mathrm{~m}$, but there was a higher number of taxa which were not found in stomach contents at $>300 \mathrm{~m}$, such as Ampelisca richardsoni,

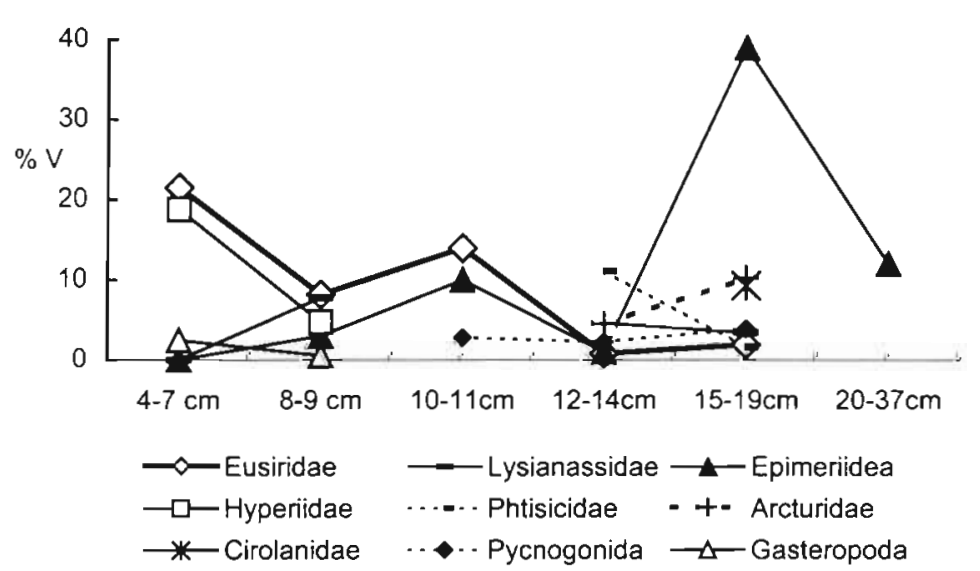

Fig. 6. Impact on amphipods, isopods and other prey in relation to predator size; data expressed in percentages of volume
Epimeria grandirostris, and the genera Pseudericthonius, Torometopa and Rhachotropis. Other taxa, such as Atyloella magellanica, were only found in stomach contents at greater depths. E. georgiana was found at all depth ranges

\section{DISCUSSION}

\section{Artedidraconids as benthic feeders}

Artedidraconids are probably the most sedentary of Antarctic fish, remaining immobile on the substratum (Hubold 1991), and catching the prey passing by. All species of this fish family feed on small prey types found at the bottom or above it, i.e. they are specialised benthic or suprabenthic feeders. The eastern Weddell Sea shelf community exhibits a high species richness and diversity (Voß 1988, Galéron et al. 1992) and is dominated by sessile suspension feeders, such as sponges and bryozoans. This sessile epifauna, whose abundance and diversity may be related to the high sedimentation rates observed (Bathmann et al. 1991) and the frequency of dropstones as nuclei of hard substrates, provides a wide variety of habitats and microhabitats to a diverse vagile fauna of gastropods, polychaetes, pycnogonids, peracarids, ophiurids and crinoids (Ekau \& Gutt 1991). In areas not covered by the sessile epibenthos, various sediment types (Gerdes et al. 1992) are colonised by sedentary polychaetes, holothurians and diverse burrowers. Some groups include a high number of species (Starmans 1993, 1997, Arntz et al. 1997), as is the case of polychaetes (Knox \& Lowry 1977, Knox 1994) and peracarids, the amphipods showing a high ecological diversity 
Table 5. Mean sizes and standard error (SE) of prey found in the stomach contents of plunderfishes sampled during ANT XV/III

\begin{tabular}{|c|c|c|c|c|c|c|c|}
\hline \multirow[t]{2}{*}{ Prey taxon } & & \multirow{2}{*}{$\begin{array}{l}\text { Length } \\
\text { range }(\mathrm{mm})\end{array}$} & \multirow{2}{*}{$\begin{array}{l}\text { No. of } \\
\text { prey }\end{array}$} & \multicolumn{2}{|c|}{ Length (mm) } & \multicolumn{2}{|c|}{ Weight (g) } \\
\hline & & & & Mean & $\mathrm{SE}$ & Mean & SE \\
\hline Crustacea & & $4-33$ & 198 & 12.1 & 5.94 & 0.3 & 0.36 \\
\hline Copepoda & & $4-5$ & 2 & 4.5 & 0.71 & 0.1 & 0.02 \\
\hline Ostracoda & & $6-11$ & 3 & 8.7 & 2.52 & 0.3 & 0.15 \\
\hline Amphipoda & & $4-33$ & 68 & 11.8 & 4.99 & 0.4 & 0.41 \\
\hline Gammaridea & & $4-33$ & 61 & 11.8 & 4.97 & 0.4 & 0.43 \\
\hline Ampeliscidae & Ampelisca richardsoni & $7-22$ & 7 & 11.7 & 4.79 & 0.2 & 0.10 \\
\hline \multirow{6}{*}{ Eusiridae } & & $11-22$ & 11 & 11.4 & 3.80 & 0.2 & 0.19 \\
\hline & Atyloella magellanica & & & 11.0 & & 0.4 & \\
\hline & Atylopsis sp. & & & 11.0 & & 0.4 & \\
\hline & Paramoera sp. & & & 9.0 & & 0.2 & \\
\hline & Prosttebingia gracilis & $8-9$ & 2 & 8.5 & 0.71 & 0.2 & 0.00 \\
\hline & Rhachotropis sp. & $12-22$ & 4 & 14.5 & 5.00 & 0.3 & 0.31 \\
\hline \multirow[t]{5}{*}{ Epimenidae } & & $8-33$ & 17 & 13.9 & 7.40 & 0.6 & 0.71 \\
\hline & Epimeria georgiana & $8-14$ & 10 & 12.0 & 1.20 & 0.3 & 0.11 \\
\hline & Epimeria grandirostris & & & 8.0 & & 0.3 & \\
\hline & Epimeria macrodonta & $12-33$ & 2 & 22.5 & 14.85 & 1.4 & 1.36 \\
\hline & Epimeria sp. & $10-32$ & 4 & 21.8 & 7.19 & 1.2 & 1.11 \\
\hline Ischyroceridae & Pseudericthonius sp. & & & 9.0 & & 0.2 & \\
\hline Leucothoidae & Leucothoe spinicarpa & & & 12.0 & & 0.2 & \\
\hline Liljeborgiidae & & $10-11$ & 2 & 10.5 & 0.50 & 0.2 & 0.04 \\
\hline \multirow[t]{5}{*}{ Lysianassidae } & & $8-13$ & 9 & 9.6 & 2.79 & 0.3 & 0.19 \\
\hline & Tryphosella murrayi & & & 4.0 & & 0.1 & \\
\hline & Tryphosella sp. & $9-13$ & 4 & 11.3 & 1.19 & 0.3 & 0.24 \\
\hline & Unistes gigas & & & 10.0 & & 0.3 & \\
\hline & Waldeckia obesa & & & 11.0 & & 0.2 & \\
\hline Stenothoidae & Torometopa sp. & & & 8.0 & & 0.2 & \\
\hline Caprellidea & & $6-23$ & 4 & 14.6 & 6.34 & 0.5 & 0.31 \\
\hline Phtisicidae & Aeginoides gaussi & $6-23$ & 4 & 14.6 & 6.34 & 0.5 & 0.31 \\
\hline Hyperiidea & & $6-13$ & 3 & 9.3 & 3.51 & 0.2 & 0.11 \\
\hline Hyperiidae & Themisto gaudichaudii & $6-13$ & 3 & 9.3 & 3.51 & 0.2 & 0.11 \\
\hline Isopoda & & $6-24$ & 11 & 14.7 & 5.81 & 0.4 & 0.42 \\
\hline Cirolanidae & Natatolana meridionalis & $20-24$ & 2 & 22.0 & 2.83 & 1.3 & 0.42 \\
\hline Gnathiidae & Gnathia sp. & $6-8$ & 2 & 7.0 & 1.41 & 0.1 & 0.03 \\
\hline Munnidae & Munna sp. & & & 12.0 & & 0.1 & \\
\hline Arcturidae & Litarcturus bobinus & $15-21$ & 5 & 17.6 & 3.01 & 0.5 & 0.16 \\
\hline \multirow[t]{2}{*}{ Cumacea } & & $9-18$ & 11 & 13.8 & 2.90 & 0.3 & 0.11 \\
\hline & Cyclaspis gigas & $9-15$ & 4 & 13.0 & 2.71 & 0.3 & 0.15 \\
\hline Decapoda & & & & 22.0 & & & \\
\hline Crangonidae & Notocrangon antarcticus & & & 22.0 & & & \\
\hline Euphausiacea & & $13-21$ & 8 & 20.0 & 2.83 & 0.7 & 0.67 \\
\hline Mysidacea & & $12-33$ & 5 & 26.8 & 8.87 & 0.4 & 0.17 \\
\hline & Antarctomysis maxima & $25-33$ & 4 & 30.5 & 3.70 & 0.4 & 0.20 \\
\hline Pycnogonida & & $10-18$ & 3 & 14.7 & 4.16 & 0.5 & 0.14 \\
\hline Polychaeta & & $6-22$ & 56 & 10.5 & 3.72 & 0.4 & 0.38 \\
\hline Nephthyidae & Aglaophanus virginis & & & 8.0 & & 0.5 & \\
\hline Terebellidae & Axionice spinifera & $12-20$ & 4 & 15.5 & 3.70 & 0.7 & 0.36 \\
\hline Maldanidae & & $7-9$ & 3 & 8.0 & 1.00 & 0.3 & 0.31 \\
\hline Phyllodocidae & Bergstroemia sotniki & $9-11$ & 3 & 10.0 & 5.07 & 0.3 & 0.10 \\
\hline Polynoidae & Polyeunoa laevis & $9-22$ & 13 & 12.2 & 3.34 & 0.8 & 0.60 \\
\hline Aphroditidae & & $13-15$ & 2 & 14.0 & 1.41 & 0.3 & 0.02 \\
\hline Spionidae & & & & 7.0 & & 0.1 & \\
\hline
\end{tabular}

and the highest species richness (De Broyer \& Jazdzewski 1993, 1996).

Polychaetes and amphipods are a trophic resource for many Antarctic benthic fish species (Gon \& Heemstra 1990, Kock 1992). Previous studies by Wyanski \&
Targett (1981) and Schwarzbach (1988) show that plunderfish feeding is completely benthic, and that they prey on a wide variety of peracarids and polychaetes, rejecting other organisms with a higher biomass, such as suspension-feeders and some detriti- 
Table 6. Numbers and weight of artedidraconid specimens found at different depths of the Weddell Sea during the ANT XV/III cruise. Data are expressed as number of individuals per trawling hour or grams per trawling hour

\begin{tabular}{|c|c|c|c|c|c|c|c|c|c|}
\hline \multirow{2}{*}{$\begin{array}{l}\text { Depth } \\
\text { (m) }\end{array}$} & \multicolumn{3}{|c|}{ Kapp Norvegia } & \multicolumn{3}{|c|}{ Vestkapp } & \multicolumn{3}{|c|}{ Halley Bay } \\
\hline & $\begin{array}{l}\text { No. of } \\
\text { indiv. }\end{array}$ & $\begin{array}{l}\text { Weight } \\
\text { (g) }\end{array}$ & $\begin{array}{l}\text { No. of preda- } \\
\text { tor species }\end{array}$ & $\begin{array}{l}\text { No, of } \\
\text { indiv. }\end{array}$ & $\begin{array}{l}\text { Weight } \\
\text { (g) }\end{array}$ & $\begin{array}{l}\text { No. of preda- } \\
\text { tor species }\end{array}$ & $\begin{array}{l}\text { No. of } \\
\text { indiv. }\end{array}$ & $\begin{array}{l}\text { Weight } \\
\text { (g) }\end{array}$ & $\begin{array}{l}\text { No. of preda- } \\
\text { tor species }\end{array}$ \\
\hline 200 & 218 & 2122 & 8 & & & & 30 & 2370 & 1 \\
\hline 400 & 102 & 354 & 5 & 32 & 1544 & 5 & 48 & 2141 & 2 \\
\hline 600 & & & & 19 & 2593 & 4 & 126 & 2810 & 1 \\
\hline 800 & & & & 2 & 1764 & 1 & 8 & 1779 & 2 \\
\hline
\end{tabular}

vores. Their preferred prey are those most readily available, due to their behaviour, size and abundance. The wide variety of bottom organisms available, and, on the other hand, the much shorter production cycle

\section{a Crustacean prey IAMPHIPODA COPEPODA DISOPODA DCUMACEA OEUPHAUSIACEA MYYSIDACEA DECAPODA QOSTRACODA}
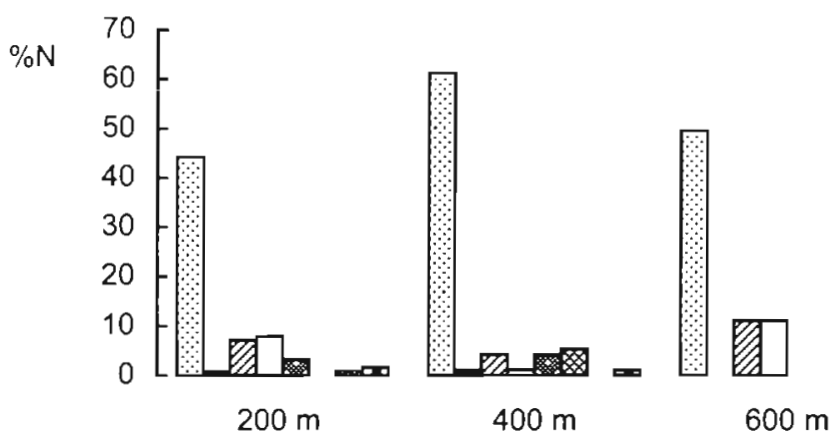

b Polychaete prey

\$APHRODITIIDAE $\triangle M A L D A N I D A E$ QNEPHTHYIDAE DPHYLLODOCIDAE

MPOLYNOIDAE ISPIONIDAE DTEREBELLIDAE
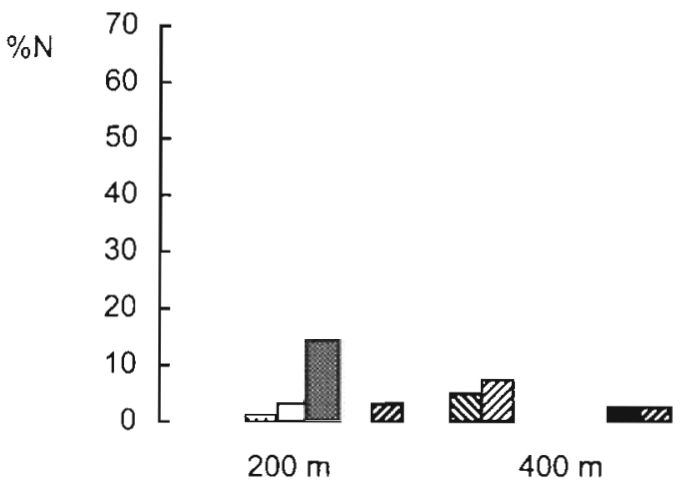

STOMACH CONTENTS 97

TOTAL PREY TAXA 42

92

25

$600 \mathrm{~m}$

25

8

Fig. 8. Differences in plunderfish feeding with depth; data expressed in number percentages and the much lower secondary production in the water column of the High Antarctic compared with more northern neighbouring areas, could have caused the evolution of these specialised benthic feeders (Kock 1992). Ross (1986) points out that there are other, not very well-known factor, which might be equally important, such as the wide variety of microhabitats.

Our detailed taxonomic determination of peracarid and polychaete prey enabled us to observe that plunderfishes prey on motile and sessile polychaetes, some groups of invertebrates, and nearly all crustacean groups. The most striking aspect was the high number of gammarid taxa consumed, mainly Eusiridae, Lysianassidae and Epimeriidae. These 3 families, along with the Stenothoidae and the Iphimedidae, are the most speciose and abundant amphipod families in the eastern Weddell Sea benthos. The absence of the common Iphimedidae in the stomach contents is noteworthy, and might be due to the repelling effect of the strong body ornamentation of teeth and spines exhibited by many iphimedids. The importance of the Eusiridae, Lysianassidae and Epimeriidae in the artedidraconid diet varies according to the predator's size-range. Kock (1992) reported that prey size increases with predator size, and that predating distance also increases. We observed a relationship which shows that there is a tendency for prey weight to rise with predator size, although the weight range of prey taxa remained almost invariable among plunderfishes measuring 5 to $17 \mathrm{~cm}$ long. In any case, we found that small fish mostly prey on animals that tend to be smaller than $10 \mathrm{~mm}$, including organisms that swim in the water column, e.g. copepods, ostracods, hyperiids, eusirids, and motile polychaetes that live in the first layers of sediment, e.g. phyllodocids and nephtyids. Plunderfishes larger than $12 \mathrm{~cm}$ 
consume walking prey - which can reach $20 \mathrm{~mm}$ (e.g. epimeriids, pycnogonids and arcturid isopods) and even $30 \mathrm{~mm}$ (e.g. swimming euphausiids, decapods and mysids)-and motile and sessile polychaetes found under and on the surface of the sediment (e.g. maldanids, polynoids, aphroditiids and terebellids).

These data on measurements of plunderfish prey confirm and expand upon the results reported by Kock (1992), who determined that the size of artedidraconid prey tends to be small, exceeding $5 \mathrm{~cm}$ only in those species that prey on other fish, such as the Pogonophryne species, whose prey can be larger than $20 \mathrm{~cm}$. In spite of these reservations, the mean prey size is probably a determining factor in the maximum size of these fishes, as already indicated for other Antarctic species by Burchett et al. (1983).

\section{Prey selectivity}

Although the High Antarctic benthos can be rich and diverse in terms of biomass and species richness (Dell 1972, Arnaud 1974, Knox \& Lowry 1977, White 1984, Jazdzewski et al. 1992), only a limited part of this benthos can serve as food for fish, because large suspension-feeders are the dominant group in terms of biomass, with sponges sometimes accounting for $90 \%$ (Arnaud 1977, Voß 1988). On the eastern Weddell Sea shelf, the surface area covered by the invertebrate benthos falls progressively from Kapp Norvegia, where it can cover $90 \%$ of the floor, to Halley Bay, where it covers < 10\% (Ekau \& Gutt 1991), affecting the distribution of the artedidraconids, which camouflage themselves among the sponges, bryozoans and hydrozoans. According to Gerdes et al. (1992), along the entire shelf, polychaetes, isopods, gammaridean amphipods and cumaceans show occurrence frequencies $>94 \%$, although they constitute only $5.5 \%$ of the total biomass. Data from Brey \& Gerdes (1998) and Gerdes (unpubl.) indicate that all of the prey groups consumed by artedidraconids represent $24.1 \%$ of the total biomass of the benthos. However, we found that prey selectivity was inversely proportional to overall environment biomass, as shown in Fig. 4. Nearly all of the peracarids were strongly preferred as prey, whereas much more abundant prey, such as non-polynoid polychaetes, were only consumed by chance, but were rarely chosen. This could be explained by the general morphological characteristics of artedidraconids, which are specialised for catching small motile prey, such as peracarids, and therefore a highly important aspect of prey selection is the plunderfish's ability to detect them.

Our data on the abundance of these plunderfishes and those of other authors (Schwarzbach 1988, Ekau
1990) do not cover the family's entire distribution area in the eastern Weddell Sea, but it can be observed that artedidraconid biomass and the number of individuals decreases with latitude. These authors found no relationship between the distribution of the benthic biomass and water depth; however, we observed that at shallower depths, the trophic spectrum was more diversified, whereas moving deeper, i.e. around $400 \mathrm{~m}$, there was more predation on gammarids and less on polychaetes, with the number of prey taxa falling progressively towards $800 \mathrm{~m}$. Like Kock (1992) and Ekau (1990), we found that fish of the genus Artedidraco were distributed down to $300 \mathrm{~m}$, with the highest numbers at around $200 \mathrm{~m}$; the genus Dolloidraco had its maximum abundance at $400 \mathrm{~m}$, and Pogonophryne was distributed from $400 \mathrm{~m}$. We also observed that the prey consumed at different depths (Fig. 8) were related to the respective selectivity and diet of the 3 genera: Artedidraco at $200 \mathrm{~m}$, Dolloidraco at $400 \mathrm{~m}$ and Pogonophryne at $600 \mathrm{~m}$ (see Table 3, Fig. 3). Therefore, these changes in artedidraconid foraging habits with depth seem mainly due to the specific diets of the genera Artedidraco, Dolloidraco and Pogonophryne, the maximum abundances of which occur where survival conditions are optimal, since the taxonomic composition of the invertebrate fauna also contributes to the number of feeding niches (Eastman \& Grande 1989). Artedidraco species prey on small peracarids and polynoids. $A$. skottsbergi forages on more phyla, 6, than any other species in the family Artedidraconidae, while $A$. orianae is the one which feeds more on different taxa, particularly gammarideans. $D$. longedorsalis is a major worm feeder, as previously reported by Schwarzbach (1988), and the diversity of its diet is quite high. In contrast $P$. marmorata rejects polychaetes and selects mysids, isopods and gammarideans of large size.

\section{Impact of artedidraconids on the eastern Weddell Sea benthos}

The trophic interactions between artedidraconids and the small mobile benthos are determined by their proportions of biomass, annual production, and consumption. Gerdes et al. (1992) found in these waters a macrozoobenthic biomass ranging between 124 and $1640 \mathrm{mg} \mathrm{m}^{-2}$ and Brey \& Gerdes (1998) observed that the biomass decreases from $26.83 \mathrm{~g} \mathrm{C} \mathrm{m}^{-2}$ in the 100 to $300 \mathrm{~m}$ stratum to $0.16 \mathrm{~g} \mathrm{C} \mathrm{m}^{-2}$ in the 1500 to $4300 \mathrm{~m}$ stratum. Likewise the community production decreases accordingly with depth from 4.83 to $0.09 \mathrm{~g} \mathrm{C}$ $\mathrm{m}^{-2} \mathrm{yr}^{-1}$. Using data obtained from these authors in a depth ranging from 135 to $550 \mathrm{~m}$, we find that the estimated biomass for the plunderfish prey groups is $3.2 \mathrm{~g}$ $\mathrm{C} \mathrm{m}^{-2}$, with low values in peracarids $\left(0.12 \mathrm{~g} \mathrm{C} \mathrm{m}^{-2}\right.$ in 
amphipods, as the most significant one) and $0.17 \mathrm{~g} \mathrm{C}$ $\mathrm{m}^{-2}$ in polynoids, while other polychaetes have a much higher wet biomass, $2.16 \mathrm{~g} \mathrm{C} \mathrm{m}^{-2}$ (Brey \& Gerdes 1998 , Gerdes unpubl. data). But the entire High Antarctic system has low productivity. In the benthos, the production proportion ranges between 0.8 and $0.1 \mathrm{~g} \mathrm{C} \mathrm{m}^{-2}$ (Brey \& Clarke 1993). Schalk et al. (1993) showed that the southeast shelf of the Weddell Sea has a mean annual macrobenthic production of 0.3 to $7.5 \mathrm{~g} \mathrm{C} \mathrm{m}^{-2}$.

The estimated fish biomass in the eastern Weddell Sea, calculated with the swept-area method, is approximately $0.91 \mathrm{t} \mathrm{km}^{-2}$ (Ekau 1990). If we take into account the fact that in our sample artedidraconid fish represented $5.6 \%$ of the total number and $1.3 \%$ of the total weight of demersal fishes, we can see that only $10 \mathrm{~kg}$ $\mathrm{km}^{-2}$ were found, i.e. $0.01 \mathrm{~g} \mathrm{~m}^{-2}$, or expressed another way $0.001 \mathrm{~g} \mathrm{C} \mathrm{m}^{-2}$. In this area, for demersal fishes, Ekau (1990) estimated the production at only $0.03 \mathrm{~g} \mathrm{C}$ $\mathrm{m}^{-2} \mathrm{yr}^{-1}$ and Hubold (1992) at $0.04 \mathrm{~g} \mathrm{C} \mathrm{m}^{-2} \mathrm{yr}^{-1}$. In order to estimate consumption by plunderfishes, we need to know their mean stomach content, digestion time, and daily feeding rates. But the digestion time in Antarctic fish is long, approximately 48 to $96 \mathrm{~h}$ (Crawford 1978, Montgomery et al. 1989), depending on the nature of the prey, size of food, and ambient temperature; in addition, when the period is longer than $24 \mathrm{~h}$, it is very difficult to detect feeding rhythms and intensity (Tarverdiyeva 1972). Also, due to their sit-and-wait predation method, these fishes do not always eat when they have already digested their previous prey. The feeding rates of Antarctic fish are low, barely reaching $2 \%$ of body weight per day (Kock 1992), so it is not surprising for these Antarctic fish to have such a low productivity level.

Artedidraconids caught during the ANT XV/III survey had a mean wet weight of $15 \mathrm{~g}$ and a mean size of $108 \mathrm{~mm}$, we can thus estimate the density to be 1 fish per $1500 \mathrm{~m}^{2}$. Using this data we can approximately calculate the value of the fish-benthos in the eastern Weddell Sea. Therefore, if plunderfishes present a density of $0.01 \mathrm{~g} \mathrm{~m}^{-2}$ and have a food intake of $2 \%$ of their body weight during the year, and we weight the percentage data by the volume of the overall plunderfish diet (Table 4), the elimination rate per day of the benthos by plunderfish is $0.2 \mathrm{mg} \mathrm{C} \mathrm{m}^{-2} 0.1 \mathrm{mg} \mathrm{C} \mathrm{m}^{-2}$ for amphipods, $0.04 \mathrm{mg} \mathrm{C} \mathrm{m}^{-2}$ for isopods, $0.04 \mathrm{mg} \mathrm{C}$

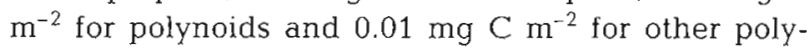
chaetes, as the most important prey groups); that it is to say that the plunderfish would consume $73 \mathrm{mg} \mathrm{C} \mathrm{m}^{-2}$ $\mathrm{yr}^{-1}$. According to Brey \& Gerdes (1998) and Gerdes (unpubl data) we assume a mean motile macrobenthic production of $1.7 \mathrm{mg} \mathrm{C} \mathrm{m}^{-2}$ in the study area (specifically $118 \mathrm{mg} \mathrm{C} \mathrm{m}^{-2}$ for amphipods, $130 \mathrm{mg} \mathrm{C} \mathrm{m}^{-2}$ for other crustaceans and $1270 \mathrm{mg} \mathrm{C} \mathrm{m}^{-2}$ for other polychaetes), of which $4 \%$ is consumed by the plunderfish.
However, precise calculations cannot be made; the present data indicate a first approximation of this fish family's consumption of the mobile benthos. Despite these limitations, we can see that the difference between the production of this mobile macrobenthos and the amount consumed by artedidraconids provides evidence that this food resource is used by other predators. In Jarre-Teichmann et al. (1997) and Arntz et al. (1994) there are examples of different species of amphipods, isopods, decapods, polynoids and aphroditiids feeding on other polychaetes and crustaceans. Olaso (1999) found only a 10\% biomass of benthic prey in the notothenioids from the eastern Weddell Sea, with the exception of the plunderfish and some Trematomus species, but some species of this genus may also prey on the motile macrobenthos (Schwarzbach 1986, 1988), although to a lesser degree than the artedidraconids. Therefore the estimations of Schalk et al. (1993) can be considered acceptable; they propose that if the ecological efficiency of these fish is about $5 \%$ (Everson 1970), $0.6 \mathrm{~g} \mathrm{C} \mathrm{m}^{-2}$ of benthic production is required in order to maintain the current mass of demersal fishes.

In the present study we also observed some qualitative aspects of the biological processes that occur in these specialised trophic relationships. On the other hand, the morphological characteristics of the fish belonging to the most abundant families of notothenioids (Nototheniidae and Channicthyidae) enable them to prey upon a wider variety of prey, and of larger size than the small amphipods and polychaetes found in the motile macrobenthos. However, since this type of prey is not always accessible, and low temperatures require fish to limit energy expenditure on predation, specialised feeding on the mobile benthos is not always manifest (Schwarzbach 1988). On the contrary, artedidraconids exploit amphipods and polychaetes because they can sit and wait for a long time under deficient consumption conditions, thus they actually exploit only a limited part of this resource.

Acknowledgements. The authors gratefully acknowledge the help of A. Brandt, C. Gambi and B. Hilbig, for identification of isopods and polychaetes. This work was conducted under the SCAR EASIZ Programme, and was supported by the Alfred Wegener Institute, by the Spanish Antarctic Programme, and by the Belgian programme Scientific Research in the Antarctic-Phase IV.

\section{LITERATURE CITED}

Arnaud PM (1974) Contribution a la bionomie marine benthique des régions antarctiques et subantarctiques. Téthys 6:465-656

Arnaud PM (1977) Adaptations within the antarctic marine benthic ecosystem. In: Llano GA (ed) Adaptations within 
antarctic ecosystems. Smithsonian Institution, Washington DC, p 135-157

Arntz WE, Gutt J (1999) The Expedition ANTARKTIS XV/3 (EASIZ II) of RV 'Polarstern' in 1998. Ber Polarforsch (Bremerhaven) 301:1-229

Arntz WE, Brey T, Gallardo V (1994) Antarctic zoobenthos. Oceanogr Mar Biol Annu Rev 32:241-304

Arntz WE, Gutt J, Klages M (1997) Antarctic marine biodiversity: an overview. In: Battaglia B, Valencia J, Walton D (eds) Antarctic communities. Cambridge University Press, Cambridge, $\mathrm{p} \mathrm{3-14}$

Balushkin AV (1988) A new species of toad beardfish, Pogonophryne curtilemma sp. n. (Artedidraconidae), from the Western Antarctica. J Ichthyol 28(1):127-130

Barnard JL, Karaman GS (1991) The families and genera of marine gammaridean Amphipoda (except marine gammaroids). Rec Aust Mus Suppl 13(1\&2):1-866

Bathmann U, Fischer G, Müller PJ, Gerdes D (1991) Shortterm variations in particulate matter sedimentation off Kapp Norvegia, Weddell Sea, Antarctica: relation to water mass advection, ice cover, plankton biomass and feeding activity. Polar Biol 11:185-195

Brandt A (1991) Colonization of the Antarctic shelf by the isopoda. (Crustacea, Malacostracea). Ber Polarforsch (Bremerhaven) $98: 1-240$

Brey T, Clarke A (1993) Population dynamics of marine benthic invertebrates in Antarctic and subantarctic environments: are there unique adaptations? Antarct Sci 5(3):253-266

Brey T, Gerdes D (1998) High Antarctic macrobenthic community production. J Exp Mar Biol Ecol 231:191-200

Burchett MS, Sayers PJ, North AW, White MG (1983) Some biological aspects of the near-shore fish populations at South Georgia. Br Antarct Surv Bull 59:63-74

Crawford RE (1978) Digestive system morphology, gastric evacuation rates and energetics in Antarctic Notothenia. PhD thesis, University of Maine, Orono

Daniels RA (1982) Feeding ecology of some fishes of the Antarctic Peninsula. Fish Bull (Wash DC) 80(3):575-588

De Broyer C, Jazdzewski K (1993) Contribution to the marine biodiversity inventory. A checklist of the Amphipoda (Crustacea) of the Southern Ocean. Vol 73. Documents de travail de l'Institut royal des Sciences naturelles de Belgique, Bruxelles

De Broyer C, Jazdzewski K (1996) Biodiversity of the Southern Ocean: towards a new synthesis for the Amphipoda (Crustacea). Boll Mus Civ Stor Nat Verona, 20, 1993 (1996): $547-568$

Dell RK (1972) Antarctic benthos. In: Russell FS, Yonge $M$ (eds) Advances in marine biology, Vol 10. Academic Press, London, p 1-216

Duhamel G, Hureau JC (1985) The role of zooplankton in the diets of certain sub-Antarctic marine fish. In: Siegfred WR, Condy PR, Laws RM (eds) Antarctic nutrient cycles and food webs. Springer-Verlag, Berlin, p 421-429

Eakın RR (1977) Morphology and distribution of species in the genus Pogonophryne (Pisces, Harpagiferidae). In: Kornicker LS (ed) Antarctic research series. Vol 31. Biology of the Antarctic Seas IX. American Geophysical Union, Washington, DC, p 81-147

Eakin RR (1981) Two new species of Pogonophryne (Pisces, Harpagiferidael from the Ross Sea, Antarctica. In: Kornicker LS (ed) Antarctic research series, Vol 31. Biology of the Antarctic Seas IX. American Geophysical Union, Washington, DC, p 149-154

Eakin RR (1987) Two new species of of Pogonophryne (Pisces, Harpagiferidae) from the Weddell Sea, Antarctica. Arch Fischwiss 38:57-74
Eakin RR (1990) Artedidraconidae. In: Gon O, Heemstra PC, (eds) Fishes of the Southern Ocean. JLB Smith Institute of Ichthyology, Grahamstown, p 332-356

Eakin RR, Kock KH (1984) Fishes of the genus Pogonophryne (Pisces, Harpagiferidae) in west Antartica and in the Weddell Sea. Arch Fischwiss 35:17-42

Eastman JT (1991) Evolution and diversification of Antarctic notothenioid fishes. Am Zool 31:93-109

Eastman JT, Grande L (1989) Evolution of the Antarctic fish fauna with emphasis on the recent notothenioids. In: Crame JA (ed) Origins and evolution of the Antarctic biota. Geol Soc Spec Publ No. 47. The Geological Society, London, p 241-242

Ekau W (1990) Demersal fish fauna of the Weddell Sea, Antarctica. Antarct Sci 2(2):129-137

Ekau W. Gutt J (1991) Nototheniod fishes from the Weddell Sea and their habitat, observed by underwater photography and television. In: Proceedings of the National Institute of Polar Research, Symposium on Polar Biology. Vol 4. NIPR, Tokyo, p 36-49

Everson I (1970) The population dynamics and energy budget of Notothenia neglecta Nybelin at Signy Island, South Georgia. Br Antarct Surv Bull 19:89-96

Galéron J, Herman RL, Arnaud P, Arntz WE, Hain S, Klages $M$ (1992) Macrofaunal communities on the continental shelf and slope of the southeastern Weddell Sea, Antarctica. Polar Biol 12:283-290

Gerdes D, Klages M, Arntz WE, Herman RL, Galeron J, Hain S (1992) Quantitative investigations on macrobenthos communities of the southeastern Weddell Sea shelf based on multibox corer samples. Polar Biol 12: 291-301

Gon O, Heemstra PC (eds) (1990) Fishes of the Southern Ocean. JLB Smith Institute of Ichthyology, Grahamstown

Gorelova T, Shandikov GA (1988) On age related changes in the food composition and diurnal feeding rhythm of Notothenia tchizh tchizh in the Lenna Bank area (Indian Sector of the Southern Ocean). J Ichthyol 28(2):86-92

Hain S (1990) The benthic seashells (Gastropoda and Bivalvia) of the Weddell Sea, Antarctica. Ber Polarforsch (Bremerhaven) 70:1-180

Hartmann-Schröder G (1986) Die Polychaeten der 56. Reise der 'Meteor' zu den South Shetland Inseln (Antarktis). Mitt Hambg Zool Mus Inst 83:71-100

Hartmann-Schröder G, Rosenfeldt P (1992) Die Polychaeten der 'Walter Herwig'-Reise 68/1 nach Elephant Island (Antarktis) 1985. Teil 1: Euphrosinidae bis Iphitimidae. Mitt Hambg Zool Mus Inst 89:85-124

Hubold KG (1991) Zur Ökologie der Fische Weddell-Meer Habilitation thesis, Christian-Albrechts-Universität, Kiel

Hubold KG (1992) Ecology of notothenioid fish in the Weddell Sea. In: di Prisco G, Maresca B, Tota B (eds) Biology of Antarctic fish. Springer-Verlag, Berlin p 3-22

Hyslop EJ (1980) Stomach contents analysis-a review of methods and their application. J Fish Biol 17:411-429

Ivlev VS (1961) Experimental ecology of the feeding of fishes. Yale University Press, New Haven, CT

Janssen J, Slattery M, Jones W (1993) Locomotion and feeding responses to mechanical stimuli in Histiodraco velifer (Artedidraconidae). Copeia 3:885-889

Jarre-Teichmann A, Brey T, Bathmann UV, Dahm C, Dieckmann GS, Gorny M, Pages F, Plotz J, Schnack-Schiel SB, Stiller M, Arntz WE (1997) Trophic flows in the benthic shelf community of the Eastern Weddell Sea. In: Battaglia B, Valencia J, Walton DWH (eds) Antarctic communities: species, structure and survival Cambridge University Press, Cambridge, p 118-134 
Jazdzewski K, Teodorczyk W, Sicinski J, Kontek B (1992) Amphipod crustaceans as an important component of zoobenthos of the shallow Antarctic sublittoral. Hydrobiologia 223:105-117

Jørgensen SE, Nielsen SN, Jørgensen LA (1991) Handbook of ecological parameters and ecotoxicology. Elsevier Science Publishers, Amsterdam

Knox GA (1994) The biology of the Southern Ocean. Cambridge University Press, Cambridge

Knox GA, Lowry JK (1977) A comparison between the benthos of the Southern Ocean and the North Polar Ocean with special reference to the Amphipoda and the Polychaeta. In: Dunbar MJ (ed) Polar oceans. Calgary: Arctic Institute of North America, Calgary, p 423-462

Kock KH (1992) Antarctic fish and fisheries. Cambridge University Press, Cambridge

Kock KH, Kellermann A (1991) Reproduction in Antarctic notothenioid fish. Antarct Sci 3(2):125-150

Krebs CJ (1972) Ecology. The experimental analysis of distribution and abundance. Harper and Row, New York

Montgomery JC, Foster BA, Cargill JM (1989) Stomach evacuation rate in the planktivorous Antarctic fish Pagothenia borchgrevinki. Polar Biol 9:405-408

Olaso I (1990) Distribución y abundanciā del megabentos invertebrado en fondos de la plataforma cantábrica. Publ Espec Inst Esp Oceanogr 5:1-128

Olaso I (1999) The pelagic fish food web. Ber Polarforsch (Bremerhaven) 301:110-118

Olaso I, Rodríguez-Marín E (1995) Decapod crustaceans in the diets of demersal fish in the Cantabrian Sea. ICES Mar Sci Symp 199:209-221

Pielou EC (1966) The measurement of diversity in different types of biological collections. J Theor Biol 13:131-144

Robb AP (1992) Changes in the gall bladder of whiting (Merlangius merlangus) in relation to recent feeding history. ICES J Mar Sci 49:431-436

Ross ST (1986) Resource partitioning in fish assemblages: a review of field studies. Copeia 2:352-388

Editorial responsibility: Otto Kinne (Editor),

Oldendorf/Luhe, Germany
Schalk PH, Brey T, Bathmann U, Arntz W, Gerdes D, Dieckmanrı G, Ekau W, Grandinger R, Plötz J, Nöthig E, Schnack-Schiel SB, Siegel V, Smetacek VS, Van Franeker JA (1993) Towards a conceptual model of the Weddell Sea ecosystern, Antarctica. In: Christensen V, Pauly D (eds) Trophic models of aquatic ecosystems. ICLARM (Int Cent Living Aquat Resour Manag) Conf Proc 26:323-337

Schwarzbach W (1986) Geographical distribution and trophic ecology of the demersal fish fauna in the eastern and southern Weddell Sea. ICES/Comm Meet (Environ Qual Comm i G:66:1-11

Schwarzbach W (1988) Die Fischfauna des östlichen und südlichen Weddellmeeres: geographische Verbreitung, Nahrung und tropische Stellung der Fischarten. Ber Polarforsch 54:1-94

Shannon CE, Weaver W (1949) The mathematical theory of communication. University of Illinois Press, Urbana

Sieg J, Wägele JW (1990) Fauna der Antarktis. Parey, Hamburg

Starmans A (1993) Strukturanalyse von Lebensgemeinschaften des Makrozoobenthos im Lazarevmeer (Antarktis). Diplomarbeit, Universität Oldenburg

Starmans A (1997) Vergleichende Untersuchungen zur Ökologie und Biodiversität des Mega-Epibenthos der Arktis und Antarktis. Dissertation, Universität Bremen

Targett TE (1981) Trophic ecology and structure of coastal Antarctic fish communities. Mar Ecol Prog Ser 4:243-263

Tarverdiyeva MI (1972) Daily food consumption and feeding pattern of the South Georgia cod (Notothenia rossi marmorata) and the Patagonia tootfish (Dissostichus elegino. ides) in the South Georgia area. J Ichthyol 20(4): 684-692

Voß J (1988) Zoogeographie und Gemeinschaftsanalyse des Makrozoobenthos des Weddellmeeres (Antarktis). Ber Polarforsch (Bremerhaven) 45:1-144

White MG (1984) Marine benthos. In: Laws RM (ed) Antarctic ecology, Vol II. Academic Press, London, p 421-461

Wyanski DM, Targett TE (1981) Feeding biology of fishes in the endemic Antarctic Harpagiferidae. Copeia 3:686-693

Submitted: February 22, 1999; Accepted: September 20, 1999 Proofs received from author(s): February 22, 2000 